\title{
THE PROTECTION OF THE RIGHT TO FREEDOM OF EXPRESSION: A PANORAMA OF THE INTER-AMERICAN COURT OF HUMAN RIGHTS CASE LAW

\author{
A PROTEÇÃO DO DIREITO À LIBERDADE DE EXPRESSÃO: UM PANORAMA DA \\ JURISPRUDÊNCIA DA CORTE INTERAMERICANA DE DIREITOS HUMANOS
}

Naiara Posenato*

\begin{abstract}
The Inter-American system for the protection of human rights recognizes the importance of freedom of expression for democratic systems. The analysis of the Inter-American Court of Human Rights (IACtHR) case law shows that it is probably the regional framework that provides the greatest scope and the broadest guarantees of protection to the right to freedom of thought and expression. Based on American Convention on Human Rights and on other relevant legislative instruments and, above all, in light of their prevailing interpretation by the aforementioned Court, this brief analysis is intended to clarify, with some comparative insights, the main features and the peculiarities of the regional system protection of the right to freedom of expression. In particular, it will consider the types of speech deserving special protection due to their importance for the exercise of other human rights or for the maintenance and the strengthening of democracy and, by contrast, the conditions according to which restrictions to freedom of expression are admitted by the Inter-American system.
\end{abstract}

Keywords: Freedom of expression. Press freedom. Inter-American Court of Human Rights (IACtHR). European Court of Human Rights (ECHR). Case-law. Protected speech. Balacing human rights. National security.
Resumo: O sistema interamericano de proteção dos direitos humanos reconhece a importância da liberdade de expressão para os sistema democráticos. A análise da jurisprudência da Corte Interamericana de Direitos Humanos revela que se trata, provavelmente, do mecanismo regional que assegura o nível mais alto de proteção e as melhores garantias para a liberdade de pensamento e expressão. Com base na Convenção Americana de Direitos Humanos e em outros instrumentos legislativos relevantes e, sobretudo, à luz da sua prevalente interpretação por parte da citada Corte, o presente ensaio busca ilustrar brevemente, com o suporte de algumas considerações comparativas, os principais aspectos e as peculiaridades do sistema regional de proteção à liberdade de expressão. Em particular, serão evidenciadas as formas de expressão destinadas a receber uma proteção especial devido à sua importância para o estabelecimento ou para a consolidação da democracia e, em sentido contrário, as condições segundo às quais o sistema interamericano admite restrições à liberdade de expressão.

Palavras-chave: Liberdade de expressão. Liberdade de imprensa. Corte Interamericana de Direitos Humanos. Corte Europeia de Direitos Humanos. Jurisprudência. Expressões protegidas. Balanceamento de direitos humanos. Segurança nacional.

\footnotetext{
"Assistant professor of comparative law and Docent of Comparative Legal Systems, Comparative Protection of Human Rights and Comparative Private Law at the University of Milan, Italy; naiara.posenato@unimi.it
} 


\section{Foreword}

The right to freedom of expression is widely protected in the legal systems belonging to the western legal tradition. It is also subject to protection by international conventions such as the Universal Declaration of Human Rights and the European Convention on Human Rights (ECHR). It is well known that freedom of expression is fundamental to personal development, the autonomy and the dignity of the individual. Its instrumental value for the exercise of other fundamental rights, such as religious freedom, cultural identity, education, among others, is also noted. However, the value nowadays more frequently associated to the exercise of this right seems to be its social dimension and close relationship with democracy, by ensuring the participation of everyone in the political debate and promoting the full information of all.

This is, indeed, a fundamental value of Inter-American system for the promotion and protection of human rights, based on which its case law recognizes the freedom of expression for democratic systems importance and states the complementary dual dimension of this right, individual and collective. On account of freedom of expression constitutes one of the essential foundations of a democratic society, this regional system deserves a special protection to public issues discourse.

According to American Convention on Human Rights (Pact of San José, Costa Rica), the exercise of the right to freedom of expression can be restricted in very limited situations. Nevertheless, freedom of expression can conflict to other rights and freedoms protected by the system and when such conflicts occurs, the Inter-American Court of Human Rights (IACtHR) shall strikes a balance in order to establish the prominence of one right over the other.

Based on relevant legislative instruments and, above all, in light of their prevailing interpretation by the aforementioned Court, these are the main points this analysis is intended to summarily clarify.

\section{The Right To Freedom Of Thought And Expression In The Inter-American System}

The Inter-American legal system, especially with regard of the Inter-American jurisprudence or case law, is probably the international framework that provides the greatest scope and the broadest guarantees of protection to the right to freedom of thought and expression. ${ }^{1}$ This is presumably due to the fact that several States of the

\footnotetext{
1 "In effect, Article 13 of the American Convention on Human Rights, Article IV of the American Declaration of the Rights and Duties of Man, and Article 4 of the Inter-American Democratic Charter offer a number of reinforced guarantees that do not appear to be equalled in the universal system or in any other regional system of protection. 4. From a comparative perspective, when the texts of Article 13 of the American Convention, Article IV of the American Declaration, and Article 4 of the Inter-American Democratic Charter are contrasted with the relevant provisions of other international human rights treaties-specifically with Article 19 of the International Covenant on Civil and Political Rights or with Article 10 of the European Convention for the Protection of Human Rights and Fundamental Freedoms-it is clear that the Inter-American framework was designed by the American States to be more generous and to reduce to a minimum the restrictions to the free circulation of information, opinions and ideas." (ORGANIZATION OF AMERICAN STATES, 2010).
} 
continent have experienced a difficult process of political transition from authoritarian or dictatorial governments, in some cases not completely accomplished. In this political context, freedom of expression violations were systematically implemented by administrative censorship, arbitrary arrest or even homicide of journalists. Currently, in light of Latin American political culture, based on institutions as the so-called "hiper-Presidenzialism" (MORALES, 2011, p. 314) and concepts such as the "delegated democracies", ${ }^{2}$ the occurrence of limitations to freedom of expression, perhaps implemented through indirect mechanisms of censorship, is not entirely excluded. The present-day importance of this right for the Inter-American system emerges from several elements, of regulatory, institutional and jurisprudential nature.

The main provision for the protection of the right to freedom of thought and expression is Article 13 of the American Convention on Human Rights, which states that

Everyone has the right to freedom of thought and expression. This right includes freedom to seek, receive, and impart information and ideas of all kinds, regardless of frontiers, either orally, in writing, in print, in the form of art, or through any other medium of one's choice. (ORGANIZATION OF AMERICAN STATES, 1969). ${ }^{32}$

Other relevant provisions are Article 14 of the American Convention of $\mathrm{Hu}-$ man Rights, ${ }^{43}$ which governs the Right of Reply, and the Article IV of the American

\footnotetext{
2 Grossman refers to the concept developed by the Argentinian political scientist Guillermo O'Donnell “[...] donde una figura carismática asume la presidencia de un país, como resultado de elecciones relativamente libres, pero gobierna sin los contrapesos de la democracia representativa.” See Grossman (2005, p. 214).

32 "Article 13. Freedom of Thought and Expression

1. Everyone has the right to freedom of thought and expression. This right includes freedom to seek, receive, and impart information and ideas of all kinds, regardless of frontiers, either orally, in writing, in print, in the form of art, or through any other medium of one's choice.

2. The exercise of the right provided for in the foregoing paragraph shall not be subject to prior censorship but shall be subject to subsequent imposition of liability, which shall be expressly established by law to the extent necessary to ensure: a. respect for the rights or reputations of others; or

b. the protection of national security, public order, or public health or morals.

3. The right of expression may not be restricted by indirect methods or means, such as the abuse of government or private controls over newsprint, radio broadcasting frequencies, or equipment used in the dissemination of information, or by any other means tending to impede the communication and circulation of ideas and opinions.

4. Notwithstanding the provisions of paragraph 2 above, public entertainments may be subject by law to prior censorship for the sole purpose of regulating access to them for the moral protection of childhood and adolescence.

5. Any propaganda for war and any advocacy of national, racial, or religious hatred that constitute incitements to lawless violence or to any other similar action against any person or group of persons on any grounds including those of race, colour, religion, language, or national origin shall be considered as offenses punishable by law." (ORGANIZATION OF AMERICAN STATES, 1969).

43 "Article 14. Right of Reply

1. Anyone injured by inaccurate or offensive statements or ideas disseminated to the public in general by a legally regulated medium of communication has the right to reply or to make a correction using the same communications outlet, under such conditions as the law may establish.

2. The correction or reply shall not in any case remit other legal liabilities that may have been incurred.

3. For the effective protection of honor and reputation, every publisher, and every newspaper, motion picture, radio, and television company, shall have a person responsible who is not protected by immunities or special privileges." (ORGANIZATION OF AMERICAN STATES, 1969).
} 
Declaration of the Rights and Duties of Man, which protects the Freedom of investigation, of opinion, and of the expression and dissemination of ideas. ${ }^{5}$

From a comparative point of view, Article 13 of the American Convention naturally has several similarities with the provision of art. 10 of the European Convention on Human Rights ${ }^{6}$ but, at the same time, reveals important peculiarities. ${ }^{7}$ For example, the American Convention, unlike the ECHR, discipline in a sole provision freedom of expression and freedom of thought. ${ }^{8}$ Second, the American conventional instrument also makes explicit reference to the right to seek and receive information and expressly prohibits prior censorship and other prior indirect restrictions. Finally, and equally important, for the Inter-American system (but not for the European one) only the individual is entitled to the protection of this right, which excludes from the category of persons protected under Article 13, for example, companies operating in the field of media and telecommunications. ${ }^{9}$

In October 2000, a further key support instrument for the interpretation of Article 13 of the Pact of San José was approved: the Declaration of Principles on Freedom of Expression. The document confirms the importance of freedom of expression protection in the continent and, at the same time, incorporates into the Inter-American system international standards for its effective exercise and guarantee. Even if this Declaration is not a legally binding instrument under International Law, according to official channels,

The idea of drafting a Declaration on Freedom of Expression arose out of recognition of the need for a legal framework to regulate the effective protection of freedom of expression in the hemisphere that would incorporate the principal doctrines set forth in different international instruments. [...] This declaration constitutes a basic document for interpreting Article 13 of the American Convention on Human Rights. Its adoption not only serves as an acknowledgment of the importance of safeguarding freedom of expression in the Americas, but also incorporates international standards into the inter-American system to strengthen protection of this right. (ORGANIZATION OF AMERICAN STATES, 1969).

\footnotetext{
5 "Right to freedom of investigation, opinion, expression and dissemination. Article IV. Every person has the right to freedom of investigation, of opinion, and of the expression and dissemination of ideas, by any medium whatsoever."

6 "ARTICLE 10 Freedom of expression

1.Everyone has the right to freedom of expression. This right shall include freedom to hold opinions and to receive and impart information and ideas without interference by public authority and regardless of frontiers. This Article shall not prevent States from requiring the licensing of broadcasting, television or cinema enterprises.

2.The exercise of these freedoms, since it carries with it duties and responsibilities, may be subject to such formalities, conditions, restrictions or penalties as are prescribed by law and are necessary in a democratic society, in the interests of national security, territorial integrity or public safety, for the prevention of disorder or crime, for the protection of health or morals, for the protection of the reputation or rights of others, for preventing the disclosure of information received in confidence, or for maintaining the authority and impartiality of the judiciary." (ORGANIZATION OF AMERICAN STATES, 1969).

7 See on the subject, among others, Úbeda de Torres (2003, p. 6-9).

8 See Morales (2011, p. 325)

$9 \quad$ In the Case $A B C$ Color $v$. Paraguay, the Inter-American Commission declared that the Government of Paraguay has violated the newspaper right to freedom of expression, but on the basis of Article IV of the American Declaration of the Rights and Duties of Men. See I/A Commission H.R., Resolution n. 6/84, Case 9250, May 17, 1984, as well as Burgorgue-Larsen e Úbeda de Torres (2011, p. 538).
} 
From an institutional point of view, support to Freedom of Expression has been introduced in 1997, with the foundation, of the Special Rapporteurship of Freedom of Expression, under the aegis of the Inter-American Commission on Human Rights. The Special Rapporteurship initial objective was grant journalists and social communicators special protection, in given the vital role they play as "public watchdog". ${ }^{10}$ In fact, in the social and political Inter-American context, the role played by journalists and social communicators in disseminating public interest information and ideas and denouncing the abuses of power, turned them into preferential victims of violation of the right to freedom of expression. ${ }^{11}$ This initial objective constitutes nowadays an element of current institution's general aim of further promoting the freedom of thought and expression in the hemisphere. ${ }^{12}$

According to ICtHR hermeneutical activities, the content of freedom of expression has a dual dimension: to the right of everyone to express his/her own opinions, ideas and information (as part of an individual's right to personal growth and self-assertion) corresponds to the community right to seek and to receive any information and ideas of any kind. Although the Court often asserts the complementary nature of these profiles, the collective dimension of the right sub analysis seems to deserve more emphasis, especially in light of its structural relationship with democratic principles. In fact, the Inter-American Court identifies as the very purpose of Article 13 of the American Convention to strengthen democratic, pluralist and deliberative systems. ${ }^{13}$

The contentious jurisdiction of the Inter-American Court on the right of freedom of expression became operative only in 2001, though the Court had beforehand addressed the interpretation of Article 13 in two Advisory Opinions. ${ }^{14}$ Therefore, any consideration about the activism of the Court in this area should be commensurate with the, after all, limited time frame in which it does interpret and apply Article 13 of the American Convention. ${ }^{15}$

\footnotetext{
${ }_{10}$ This expression has been employed by the European court of human rights for the first time in Lingens v. Austria, no. $8215 / 82, \S 44$.

11 According to reported data, from 2010 to date, 150 journalists and media workers were killed in the Americas, allegedly for reasons related to the exercise of freedom of expression. In the regional context, one in three of the killings documented by Office of the Special Rapporteur for Freedom of Expression occurred in Mexico (55 in total), and almost one in five happened in Honduras (28 in total). Brazil, with 25 murders, ranked third on the list. Colombia (11), Guatemala (9) Peru (6) and Paraguay (4) are also countries where this issue is a real problem in the period studied. In the previous decade, such violence was also at these levels, although the magnitude varied depending on the country, and also impunity rates were deplorable. See Office of the Special Rapporteur for Freedom of Expression, Press Release R124/15, 2015. See also Violence against journalists and media workers: Inter-American standards and national practices on prevention, protection and prosecution of perpetrators. III. Series. OAS official records; OEA/Ser.L. OEA/ Ser.L/V/II CIDH/RELE/INF.12/13. Document prepared by the Special Rapporteur for Freedom of Expression of the Inter-American Commission on Human Rights, 2013 (ORGANIZATION OF AMERICAN STATES, 2010).

12 For further details on its composition and functions, as well as working methods, see the website <http://www. oas.org/es/cidh/>.

13 Extensively on the topic, see Morales (2011, p. 313-324).

14 I/A Court H.R., Compulsory Membership in an Association Prescribed by Law for the Practice of Journalism (Arts. 13 and 29 American Convention on Human Rights). Advisory Opinion OC-5/85 of November 13; and I/A Court H.R., Enforceability of the Right to Reply or Correction (Arts. 14(1), 1(1) and 2 American Convention on Human Rights). Advisory Opinion OC-7/85 of August 29, 1986, both presented by the government of Costa Rica.

15 The European Court has given the first judgment in the matter on Dec. 7, 1976, with the decision of the case Handyside $v$. the United Kingdom, n. 5493/72.
} 
The mentioned relationship between democratic regimes and the freedom of expression has been highlighted by the Court for the fist time in the Advisory Opinion $O C-5 / 85$, issued in respect of a request presented by Costa Rica concerning the compatibility of freedom of expression with the compulsory membership of journalists to their order for the exercise of the profession, imposed by the Law no. 4420, of 22 September 1969 (Ley Orgánica del Colegio de Periodistas de Costa Rica). ${ }^{16}$ In its opinion, the Inter-American Court declared the incompatibility of compulsory membership of journalists to exercise their profession with the Article 13 of the American Convention (and, therefore, of the Ley Orgánica of the Colegio de Periodistas de Costa Rica), where it prevents access to any person to the full use of social media as a vehicle to express themselves or to convey information. Ten years later, the Constitutional Hall of the Supreme Court of Costa Rica has accepted in full the criteria pronounced by the Inter-American Court and declared the Law no. 4420/85 unconstitutional. ${ }^{17}$

\section{The Types Of Speech Protected By The System}

In principle, Article 13 of American Convention protects all forms of speeches, independently of their content, and such protection extends to the dissemination of the information or the opinion itself, regardless of the medium used.

The silence is also considered a form of expression, as evidenced by a case whose treatment has exhausted at the level of Inter-American Commission in 1998, Jehovah's Witnesses against Argentina. ${ }^{18}$ According to the Inter-American Commission, the South American State had violated several articles of American Convention as a result of a persecution policy against people and children belonging to that religion, which have been banned in Argentina, also because they refused to honour the country symbols of the homeland and singing the national anthem.

The right to freedom of expression must be guaranteed independently of the information or the opinion degree of social acceptance. This general assumption is linked to the State's primary duty of content-neutrality and to the need that no individuals, groups, ideas or means of expression should be a priori excluded from public debate. Therefore, even information that are not welcomed, but rather disturbing, offensive, provocative, shocking or unpleasant are guaranteed by the Inter-American system, in the name of pluralism. This statement is on the basis of the Inter-American Court judg-

\footnotetext{
16 See Compulsory Membership in an Association, passim. On paragraph 70 the Court affirms that "Freedom of expression is a cornerstone upon which the very existence of a democratic society rests. It is indispensable for the formation of public opinion. It is also a conditio sine qua non for the development of political parties, trade unions, scientific and cultural societies and, in general, those who wish to influence the public. It represents, in short, the means that enable the community, when exercising its options, to be sufficiently informed. Consequently, it can be said that a society that is not well informed is not a society that is truly free."

17 See Pasqualucci (op. cit., p. 77).

18 I/A Commission H.R., Jehovah's Witnesses against Argentina, Case 2137, November 18, 1978.
} 
ment in the case The Last Temptation of Christ (Olmedo Bustos y otros) $v$. Chile, of 2001. ${ }^{19}$ The facts of this case occurred in 1988, when the Cinematographic Classification Council of Chile has refused to allow the exhibition of the film "The Last Temptation of Christ", considered to be blasphemous. Questioned about it, the Court decided that Chile had violated the right to freedom of thought and expression embodied in Article 13 of the American Convention and ordered the State to amend its domestic law, eliminate prior censorship and compensate the victims. In this occasion, the Court also stressed that the right to freedom of expression doesn't apply only to speech and to the written word. ${ }^{20}$

If all forms of expression are in principle protected by Article 13 of the American Convention, certain types of speech receive special protection because of their importance for the exercise of other human rights and, especially, for the maintenance and strengthening of democracy, in line with the Inter-American Court special attention for the protection of the right to freedom of expression collective dimension. For the Inter-American Court, three types of speech deserve special protection: (a) political speech or speech involving matters of public interest; (b) speech regarding public officials in the exercise of their duties or candidates to public offices; and (c) speech that is an element of identity or personal dignity of the person expressing herself (ORGANIZATION OF AMERICAN STATES, 2009, p. 11).

In several occasions, the Court held that a democratic and pluralistic system requires the highest possible degree of public debate on social questions and on the functioning of the State in all its aspects, that is, on matters of public interest. Similarly, State and its officials acts and omissions must undergo rigorous scrutiny, not only by the internal control bodies, but also by the press and public opinion, because public administration democratic control promotes transparency in the activities of government and the responsibility of public officials for their actions, as well as encourage a higher level of citizen participation. For these reasons, speeches relating to matters of public interest and involving public officials or individuals performing public functions are specially protected by the Inter-American system. This implies that States must refrain more rigorously to establish limitations on these forms of expression, and that the State officials, its organs, along with those who aspire to public offices, should have a threshold higher tolerance for criticism because of the public nature of the functions they perform.

The Court asserted this principle in several occasions; for instance, in the case Case Ivcher Bronstein ${ }^{21}$ of 2001, when Peruvian State unlawfully deprived $\mathrm{Mr}$ Ivcher Bronstein of his nationality, in order to remove him from the editorial control of a television channel that broadcasts services related to secret services, during the government of then President Fujimori. In this case, the Court founded that the State violated Article 13 of the American Convention, and also stated that "[...] the

\footnotetext{
19 I/A Court H.R., Case of The Last Temptation of Christ (Olmedo-Bustos et al.) v. Chile. Merits, Reparations and Costs. Judgment of February 5, 2001.

20 Case of The Last Temptation of Christ (Olmedo-Bustos et al.) v. Chile, para. 65.

${ }^{21}$ I/A Court H.R., Case of Ivcher-Bronstein v. Peru. Merits, Reparations and Costs. Judgment of February 6, 2001.
} 
State not only restricted their right to circulate news, ideas and opinions, but also affected the right of all Peruvians to receive information, thus limiting their freedom to exercise political options and develop fully in a democratic society." 22 And that

[...] it is essential that the journalists who work in the media should enjoy the necessary protection and independence to exercise their functions comprehensively, because it is they who keep society informed, and this is an indispensable requirement to enable society to enjoy full freedom. ${ }^{23}$

The importance of questions of public interest has been highlighted in Case Usón Ramírez $v$. Venezuela decision, of 2009. ${ }^{24}$ The facts of the case concerned the retired military general Usón Ramírez conviction for "insult against the Armed Forces", as he had criticized the institution's reaction in the case of a group of soldiers who had been severely injured while in a punishment cell. The Court considered that the applicant statements should be particularly protected as they referred to State agencies on which, in that moment, there was a great public debate. ${ }^{25}$

In Ricardo Canese $v$. Paraguay, of $2004,{ }^{26}$ the facts reveal the lodge of defamation criminal proceedings against then presidential candidate Ricardo Canese, for the reason that he disclosed information about the past of his political rival, and his presumed links with the former dictator Stroessner, in the context of an election campaign. The Inter-American Court held that Paraguay had violated the victim's right to freedom of expression taking into account, among other things, that statements had been made during a presidential election campaign on issues of public interest, "[...] circumstances in which opinions and criticisms are issued in a more open, intense and dynamic way, according to the principles of democratic pluralism." ${ }^{27}$ For this reason, according to the decision, the judge would have to balance the respect of the rights or reputations of others with the value that acquires, in a democratic society, the open debate on the issues of public interest.

A fairly recent controversy that presents several relevant aspects on the matter is the Case Kimel $v$. Argentina, of $2008 .^{28}$ In this case the writer and journalist Mr. Eduardo Kimel, has been condemned for the crime of defamation and ordered to pay monetary compensation since he had published the book "La masacre de San Patricio". In the book, he analysed the murder, during the military dictatorship, of

\footnotetext{
${ }^{22}$ Case of Ivcher-Bronstein v. Peru, para. 163. The Inter-American Court expressly referred to the European system of protection of human rights case law on matters of public interest and, in particular, to cases Feldek v. Slovakia, of 1995, and Surek and Özdemir $v$. Turkey, of 1999.

${ }^{23}$ Case of Ivcher-Bronstein v. Peru, para. 150.

${ }^{24}$ I/A Court H.R., Case of Usón Ramírez v. Venezuela. Preliminary Objection, Merits, Reparations and Costs. Judgment of November 20, 2009.

25 "Despite the existence of public interest regarding the events in Fuerte Mara, to which the Armed Forces depends, Mr. Usón Ramírez was tried and judgment without taking into account the requirements of the American Convention regarding the larger tolerance required regarding any affirmations and considerations expressed by citizens exercising their democratic right”. See Case of Usón Ramírez v. Venezuela, para. 84.

${ }_{26}$ I/A Court H.R., Case of Ricardo Canese v. Paraguay. Merits, Reparations and Costs. Judgment of August 31, 2004.

27 Case of Ricardo Canese $v$. Paraguay, para. 105.

28 I/A Court H.R., Case Kimel v. Argentina. Merits, Reparations and Costs. Judgment of May 3, 2008.
} 
five clergymen and criticized the Argentinian authorities, and one federal judge in particular, for not having adequately investigated the crime. The Court ruled that Argentina had violated its international obligations under Article 13 of the American Convention by taking into account, among other factors, (i) that Mr. Kimel's criticism was with respect to issues of notorious public interest; and (ii) that the book in question concerned the actions of a judge in the exercise of his official duties.

This case is interesting because it constitutes an illustration of special protected discourse concerning public officials in the exercise of their duties or candidates to public offices. Another significant issue that have emerged deals with the difference between an opinion and the imputation of a fact, ${ }^{29}$ and the journalists duty to verify reasonably, though not necessarily in an exhaustive manner, the accuracy of the facts supporting their opinion. Therefore, it is valid to claim equity and diligence in the search for information and the verification of the sources, because of general journalists' credibility and in order to prevent that citizens receive a distorted version of the events. ${ }^{30}$

A third type of expression that enjoys special protection under the American Convention involves forms of speech that express constituent elements of personal identity or dignity of those who express. The ICtHR ruled on the issue in the case Lopez Alvarez $v$. Honduras, of 2006, ${ }^{31}$ related to the prohibition imposed by the director of an Honduran detention centre for confined Garifuna people to speak their own language. In particular, the Court considered that the prohibition was not only unnecessary and unwarranted, but also particularly severe, since the language is one of the most important elements of identity of any people and guarantees the expression, dissemination and transmission of its culture..$^{32}$

The right to have access to information has recently made incursion in the Inter-American case law, by the Case Claude Reyes y otros c. Chile, of $2006 .^{33}$ This decision is symptomatic of a turning point on the topic, as it gave the opportunity to

\footnotetext{
29 "The opinions expressed by Mr. Kimel can neither be deemed to be true nor false. As such, an opinion cannot be subjected to sanctions, even more so where it is a value judgment on the actions of a public official in the performance of his duties. In principle, truthfulness or falseness may only be established in respect of facts. Hence, the evidence regarding value judgments may not be examined according to truthfulness requirements." In Case Kimel v. Argentina, para. 93.

${ }^{30}$ Case Kimel v. Argentina, para. 79. The European court reached a similar conclusion in the Case Lingens v. Austria (Application no. 9815/82), Judgment of 8 July 1986, para. 46 and in the Case Bergens Tidende v. Norway (Application no. 26132/95). Judgment of 2 May 2000, para. 53.

In the Case of Perozo et al. $v$. Venezuela, of 2009, concerning a series of violent actions by private individuals against the television station Globovisión and its workers, the Inter-American Court has found the Venezuelan State responsible for violations of Article 13 (freedom of thought and expression). The attacks took place in the context of declarations by highranking public officials referring to Globovisión and its owners and executives as "enemies of the revolution", "enemies of the people of Venezuela", "fascist", and participants in the 2002 coup d'état against President Hugo Chávez. The Court stressed that public officials enjoy freedom of expression, but must exercise this freedom with particular discretion in contexts of social unrest, lest their statements place individuals at greater risk of violence. See I/A Court H.R., Case of Perozo et al v. Venezuela. Preliminary Objections, Merits, Reparations and Costs. Judgment of January 28, 2009 , para. 139. 31 I/A Court H.R., Case of López-Álvarez v. Honduras. Merits, Reparations and Costs. Judgment of February 1, 2006.

32 Case of López-Álvarez v. Honduras, para. 171.

33 I/A Court H.R., Case of Claude-Reyes et al. v. Chile. Merits, Reparations and Costs. Judgment of September 19, 2006. The case concerns the international responsibility of the Chilean State for the refusal to provide information about a forestry project to Marcel Claude Reyes and the lack of an adequate and effective remedy for challenging the decision. The ruling was considered by the European Court on Human Rights in Stoll c. Switzerland (Application no. 69698/01), December 10, 2007, para. 43.
} 
Inter-American judge to exploit the Article 13 potentiality. Unlike in the analogous European Convention, this article does recognize the right of each individual to search and to have access to any type of public information, and the corresponding obligation of the State to provide it. ${ }^{34}$ The Court provided further clarification on the exercise of this right in Case Gomes Lund v. Brasil (Guerrilha do Araguaya), of 2010. ${ }^{35}$ In this case, 25 years had passed from the presentation of access to information request (made by relatives of victims of enforced disappearance during military operations against guerrillas in the Brazilian Araguaia region), and the delivery of the first documents by the State agencies involved. The Court has condemned Brazil for the violation of freedom of expression enshrined in Article 13 of the American Convention on the grounds that the requests should also be dealt within a reasonable time.

Notwithstanding the $a b$ initio coverage of all forms of human expression by the right to freedom of expression, according to Article 13 of the American Convention, certain types of speech are excluded from this protection. They are of essentially two types: the propaganda of war and advocating hatred that constitutes incitement to violence (hate speech) and the child pornography. On the topic, Article 13.5 of the American Convention expressly provides that

[...] any propaganda for war and any call to hatred of national, racial or religious hatred that constitutes incitement to lawless violence or to any other similar action against any person or group of people for any reason, including because of race, colour, religion, language or national or social origin shall be considered as offenses punishable by law. (ORGANIZATION OF AMERICAN STATES, 1969).

The Commission has indicated, following the doctrine and international jurisprudence, in particular from the European Court of Human Rights, that the imposition of sanctions for abuse of freedom of expression on charges of incitement to violence (understood as incitement to commit crimes, the threat to public order or national security) has to be based on the actual demonstration that the person was not simply expressing an opinion (even if harsh, unjust or provocative) but also that had the clear intention of inciting violence, as well as the current, real and effective possibility to achieve his objectives (ORGANIZATION OF AMERICAN STATES, 2009, p. 20-21). With regard to the issue, the doctrine also noted that the so-called "hate speech" is differently defined by the Inter-American legal discipline respect to the European system: in the Americas, the inciting to violence is required to hate-speech characterization and, therefore, the system imposes a tighter criteria for its definition (BERTONI, 2006, p. 573-574).

Concisely on the topic, it should be remembered that the Strasbourg system applies also a content-based restriction to freedom of expression on the basis of dissemination of ideas promoting racism and Nazi ideology. For instance, in Kühnen v. the Fed-

\footnotetext{
34 For discussion on this matter see Burgorgue-Larsen and Úbeda de Torres (2003, p. 536-538).

35 I/A Court H.R., Case of Gomes Lund et al. (Guerrilha do Araguaya) v. Brasil. (Preliminary Objections, Merits, Reparations, and Costs). Judgment of November 24, 2010.
} 
eral Republic of Germany, of 1988, the European Commission declared inadmissible Mr. Kühnen application against his conviction for spreading propaganda directed against the basic order of democracy, on the basis of his attempt to re-institute the Nazi party in Germany. ${ }^{36}$ Denial of the Holocaust was also denied the protection of Article 10 ECHR. ${ }^{37}$

A paradigmatic judgment on the topic of Hate speech, even if high controversial, is Case Féret $v$. Belgium, of 2007. In this case, the Court held by four votes to three that there had been no violation of Article 10 of the European Convention of Human Rights in respect of the conviction of the chairman of the Belgian political party "Front National", Mr. Daniel Féret, for publicly inciting discrimination or hatred following complaints concerning leaflets distributed by that party during election campaigns. The need to avoid comments that might foster intolerance has been recognized, specially in case of politicians or public persons, as well as has been clarified that, in some circumstances, racist or xenophobic discourse can, di per se, provoke violence:

73. La Cour estime que l'incitation à la haine ne requiert pas nécessairement l'appel à tel ou tel acte de violence ou à un autre acte délictueux. Les atteintes aux personnes commises en injuriant, en ridiculisant ou en diffamant certaines parties de la population et des groupes spécifiques de celle-ci ou l'incitation à la discrimination, comme cela a été le cas en l'espèce, suffisent pour que les autorités privilégient la lutte contre le discours raciste face à une liberté d'expression irresponsable et portant atteinte à la dignité, voire à la sécurité de ces parties ou de ces groupes de la population. Les discours politiques qui incitent à la haine fondée sur les préjugés religieux, ethniques ou culturels représentent un danger pour la paix sociale et la stabilité politique dans les Etats démocratiques.

Child pornography is prohibited in absolute terms by American Convention on Human Rights, in particular by its Article 13.5, in conjunction with Article 19, according to which "every minor child has the right to the measures of protection required by his condition as a minor on the part of his family, society, and the State". Child pornography, as well as all forms of discourse violently abusive of children rights or contrary to their interests, should therefore be excluded from protection within the Inter-American system.

\section{Restrictions And Balance With Other Rights}

The American Convention, as well as other international human rights instruments, states the possibility to restrict the right to freedom of expression under certain conditions, ${ }^{38}$ set out in paragraphs 2,3 and 4 of Article 13:

\footnotetext{
36 "With reference to the present case the Commission notes thatthe provisions of German penal law under which the applicant was convicted and sentenced aimed at protecting the basic order of freedom and democracy and the notion of the understanding among peoples. The aim was, therefore, legitimate under Article 10 para. 2 (Art. 10-2) as being established "in the interests of national security (and) public safety (and) for the protection of the ... rights of others." Cfr. Kühnen v. the Federal Republic of Germany, no 12194/86, "The Law", para. 1.

37 Garaudy v. France, no. 65831/01; Honsik v. Austria, no. 25062/94.

38 As stated by the Inter-American Court in one of its first ruling on the topic, the American Convention text contains a much shorter list of restrictions than does the European Convention on Human Rights and the International Covenant on Civil and Political Rights). See Compulsory Membership in an Association prescribed by law for the practice of journalism, para. 45.
} 
Article 13. Freedom of Thought and Expression [...] 2. The exercise of the right provided for in the foregoing paragraph shall not be subject to prior censorship but shall be subject to subsequent imposition of liability, which shall be expressly established by law to the extent necessary to ensure: a. respect for the rights or reputations of others; or b. the protection of national security, public order, or public health or morals. 3 . The right of expression may not be restricted by indirect methods or means, such as the abuse of government or private controls over newsprint, radio broadcasting frequencies, or equipment used in the dissemination of information, or by any other means tending to impede the communication and circulation of ideas and opinions. (ORGANIZATION OF AMERICAN STATES, 1969).

\section{According to renowned doctrine,}

The originality of Article 13 is that it incorporates the major categories of restrictions into a general scheme based on the principle that the technical means of disseminating ideas, opinions, information or works of art should not be used as a way of restricting the freedom of expression (Art. 13.2 and 13.3). In so doing, the American Convention insists on the principle of unfettered freedom of expression, or at least one with the fewest possible restriction, and that the reason for these restrictions is to protect the general interest and the rights of others (13.2). (BURGORGUE-LARSEN; ÚBEDA DE TORRES, 2011, p. 548).

The second paragraph of Article 13 determines the prescription of censorship and authorizes only subsequent imposition of liability to the abusive exercise of the right to freedom of expression. The express prohibition of a priori direct and indirect limitations to freedom of expression - and measures tantamount to censorship - characterizes the Inter-American system legal framework; it has not been previewed, for instance, by the European system, which, however, had set up a regional body to control how censorship was implemented. ${ }^{39}$ From 2001, when the case La Última Tentación of Christ (Olmedo Bustos y otros) v. Chile was decided, the Inter-American Court considered the question of prior censorship several times. ${ }^{40}$ The third paragraph of Article 13 also prohibits restrictions that may indirectly affect the exercise of freedom of expression, and it provides a list - not exhaustive - of these measures: "[...] the abuse of public or private controls on the periodical press, the frequencies for radio

\footnotetext{
39 See Grossman (2005, p. 233-234). On the topic, see ECtHR, Observer and Guardian v. The United Kingdom, no. $13585 / 88, \S 60$ : "For the avoidance of doubt, and having in mind the written comments that were submitted in this case by "Article 19" (see paragraph 6 above), the Court would only add to the foregoing that Article 10 (art. 10) of the Convention does not in terms prohibit the imposition of prior restraints on publication, as such. This is evidenced not only by the words "conditions", "restrictions", "preventing" and "prevention" which appear in that provision, but also by the Court's Sunday Times judgment of 26 April 1979 and its markt intern Verlag GmbH and Klaus Beermann judgment of 20 November 1989 (Series A no. 165). On the other hand, the dangers inherent in prior restraints are such that they call for the most careful scrutiny on the part of the Court. This is especially so as far as the press is concerned, for news is a perishable commodity and to delay its publication, even for a short period, may well deprive it of all its value and interest." But see also, in the same case, the De Meyer J Dissenting opinion (concerning prior restraint), joined by judges Pettiti, Russo, Foighel and Bigi, in which he argued that prior restraint is generally prohibited by the Convention.

40 See, on the issue, González (2006, p. 2006, p. 239 e ss).
} 
broadcasts, or the instruments for the dissemination of information, or by any other means tending to impede the communication and circulation of ideas and opinions."

The Case Ivcher Bronstein concerned an indirect violation of the right to freedom of expression and it is an illustration that although the Convention does prohibit indirect restrictions on freedom of expression, identifying such restrictions is not always simple (BERTONI, 2009, p. 332-352).

According to the American Convention, ex Article 13.4, exceptions to prohibition of prior censorship can only be admitted "[...] in order to protect the morals of children and adolescents."

Pursuant to the second paragraph of Article 13, as interpreted by the Inter-American Court, restrictions on freedom of expression must meet several requirements of general and substantial nature. Primarily, the provision requires that such limitations are expressly provided by law and, in this sense, the Inter-American Court has made clear that the relevant national legal provisions should be clear and specific, and define in unequivocal terms the unlawful conduct. ${ }^{41}$ Then, Article 13.2 of American Convention raises substantial parameters to determine the legality of the admitted restrictions on freedom of expression: first of all, they should be absolutely necessary in a democratic society, i.e. the restrictions must be justified by collective goals that take precedence over freedom of expression and, at the same time, do not restrict this freedom so necessary for achieving this objective, interfering as little as possible with its exercise. ${ }^{42}$ Also, if there is obvious damage or threat to the rights of third parties, it is necessary that those rights have been damaged or threatened, and the burden of proof is on the party seeking the limitation. In other words, the State must prove that restriction of freedom of expression is absolutely necessary to protect a right actually threatened or injured.43

The protection of "Right to Privacy", according to Article 11 of the American Convention $^{44}$ and, in particular, the protection of honour and reputation, can lead to freedom of expression restrictions, or rather, as allowed by the Inter-American system, can determine subsequent responsibility for the improper exercise of this freedom. Under that provision, the Inter-American system of protection of human rights

\footnotetext{
${ }_{41}$ Case Kimel v. Argentina; Case Uson Ramírez v. Venezuela.

42 Case Ricardo Canese v. Paraguay.

${ }^{43}$ Compulsory Membership in an Association Prescribed by Law for the Practice of Journalism, paras. 41 to 46 . In this last paragraph the Court states that "It is important to note that the European Court of Human Rights, in interpreting Article 10 of the European Convention, concluded that "necessary," while not synonymous with "indispensable," implied "the existence of a "pressing social need" "and that for a restriction to be "necessary" it is not enough to show that it is "useful," "reasonable" or "desirable." (Eur. Court H. R., The Sunday Times Case, judgment of 26 April 1979, Series A no. 30, para. 59, p. 35-36). This conclusion, which is equally applicable to the American Convention, suggests that the "necessity" and, hence, the legality of restrictions imposed under Article 13 (2) on freedom of expression, depend upon a showing that the restrictions are required by a compelling governmental interest [...]"

44 "Article 11. Right to Privacy

1. Everyone has the right to have his honor respected and his dignity recognized.

2. No one may be the object of arbitrary or abusive interference with his private life, his family, his home, or his correspondence, or of unlawful attacks on his honor or reputation.

3. Everyone has the right to the protection of the law against such interference or attacks."
} 
recognizes that every person has the right to privacy and prohibits any arbitrary or abusive interference with that right, that

[...] may include, among other dimensions, the freedom to make decisions related to various areas of a person's life, a peaceful personal space, the option of reserving certain aspects of private life, and control of the dissemination of personal information to the public..$^{45}$

Since, however, a defined hierarchy between these rights does not exist, in case of antimony a balancing exercise must be performed. However, the task is not always simple, and should be done by means of a casuistic approach, that is, in the light of the concrete circumstances of each case the situations that deserve protection.

For this reason, for instance, according to the Inter-American Court, the protection of the reputation of public officials must be balanced with the greater protection afforded to expressions related to these figures. This is justified, among other things, by the importance of maintaining a legal framework that promotes public deliberation, and also on the basis that officials voluntarily subject themselves to increased social control. In this regard, the Court ruled in the Case Tristan Donoso v. Panama, of 2009, ${ }^{46}$ that

[...] international law provides that the honour protection threshold of a public official should allow extensive control of citizens on the performance of their duties [...]. This differentiated protection explains why public officials voluntarily expose themselves to the control of the company, leading to a higher risk of damage to his honour, as well as the opportunity associated with their condition, have greater social influence and ease of access to the media to explain or account for acts involving. ${ }^{47}$

The dispute concerned the situation of Mr. Tristán Donoso, a Panamanian attorney, convicted of defamation against the Attorney General of the State, because of statements relating to his corrupt behaviour. The Court found that criminal conviction imposed was not necessary in a democratic society and that the State violated the American Convention on Human Rights.

In this regard, an illustrative decision of the Inter-American Court, which dates to 2011, is the judgment of Case Fontevecchia and D'amico v. Argentina. ${ }^{48}$ The facts relate to an order to pay damages imposed by Argentinian civil courts to Jorge Fontevecchia and Hector D'Amico, journalists of the magazine Noticias, for the disclosure of personal information about the then-President of Argentina, Mr Carlos Saúl Menem, and for violation of his right to privacy. The Inter-American Court considered, otherwise, that there had been no abusive or arbitrary interference by journalists in the private life of Mr Menem and condemned Argentina for violation of

\footnotetext{
${ }_{45}$ I/A Court H.R., Case Fontevecchia and D'Amico v. Argentina. Merits, Reparations, and Costs. Judgement of November 29, 2011, para. 48.

${ }^{46}$ I/A Court H.R., Case of Tristán Donoso v. Panama. Preliminary Objection, Merits, Reparations and Costs. Judgment of January 27, 2009, para. 115.

47 Case of Tristán Donoso vs. Panama, para. 122.

48 Case Fontevecchia and D'Amico v. Argentina.
} 
Article 13 of American Convention. The Court took into account Mr Menem conduct as well as the public interest in the matter. ${ }^{49}$ The case is interesting because it reveals a conflict between two rights equally protected in the American Convention, namely the freedom of expression (art. 13) and the right to privacy (art. 11). ${ }^{50}$

Further development towards a more balanced equilibrium between freedom of expression and the right to privacy emerges in Case Mémoli v. Argentina, of $2013 .{ }^{51}$ Carlos and Pablo Mémoli were criminally convicted in 1994 for accusing the members of the Governing Council of the Italian "Porvenir de Italia" of illegal conduct relating to the sale of niches in the local cemetery. The Court decided that the domestic judgments did not violate the freedom of expression of Messrs Mémoli as: (i) it was based on a rule of Argentinian law which was in force; (ii) the legislation had a legitimate purpose, compatible with the Convention, i.e. protection of honour and reputation of others; (iii) certain expressions used by Messrs Mémoli could foreseeably lead to criminal prosecution for violation of the honour or reputation of those affected; (iv) the use of judicial measures to protect the honour and reputation of individuals is valid and legitimate under the American Convention; (v) the judicial authorities of Argentina have played a reasonable balance between the right to freedom of expression and the right to honour and reputation of others; (vi) the matters to which the incriminating statements referred were not of public interest, and (vii) the penalties imposed on Messrs Memoli were not manifestly excessive or disproportionate so to affect the freedom of expression. The Court, though with four votes in favour and three against, considered the State is not responsible for the violation of the right to freedom of expression.

The second paragraph of Article 13 of the American Convention also states that freedom of expression can be limited in view of the protection of national security or of public health or morals. The arrangement, however, has been interpreted narrowly by the Inter-American organs, also to prevent that this possibility, given their potential magnitude, should be used to suppress effectively the right to freedom of expression, or deprive it of any real content. In this way, it is clearly stated that, to any penalty imposed in the name of defending the public order (understood as security, public health or morality) is necessary to demonstrate that the concept of "order" is not authoritarian, but a democratic one, understood as the existence of structural conditions for all people, without discrimination, to exercise their rights in freedom, with vigour and without fear of being punished for it. If this concept is invoked as a ground for limiting human rights, it must be strictly interpreted, taking into account the balance between the different interests at stake and the need to preserve the object and purpose of the Convention.

In any case, if the exercise of freedom of expression is abusive and causes injury to the rights of others, in compliance with strict parameters mentioned above,

\footnotetext{
49 Case Fontevechia and D'Amico v. Argentina, paras. 60 and 65.

50 The court deemed necessary to find a balance between the right to life and to personal privacy and freedom of expression which considered to be two fundamental rights of great importance in a democratic society. Case Fontevecchia and D'Amico v. Argentina, para. 50.

51 I/A Court H.R., Case Mémoli v. Argentina. Preliminary objections, merits and costs. Judgment of August 22, 2013.
} 
least restrictive measures to freedom of expression should be utilized to repair the damage: first of all, the right of reply enshrined in Article 14 of the American Convention. If that is insufficient, and if the material injury is due to an intentional act of causing damage or a blatant disregard for the truth is proved, then the abuse of freedom of expression may lead to the imposition of liability. ${ }^{52}$

The Inter-American jurisprudence is also significant on how to prosecute any excesses in the exercise of freedom of expression. On the basis of the mentioned general principles, namely that any restriction must be prescribed by law, pursue a legitimate aim and be necessary in a democratic society, the position of those States that limit the freedom of expression by means of drastic remedies - ius puniendi - has always be criticized. The Principle 11 of the Declaration of Principles on Freedom of Expression expressly states it,,$^{53}$ and the political line of American institutions - in the wake of the work of the Inter-American Commission and, more particularly, of the Office of the Special Rapporteur for Freedom of Expression - is towards decriminalization in continent of defamatory behaviour. The concurring opinion of Judge García Ramírez in the Case Herrera Ulloa v. Costa Rica, of 2004 is paradigmatic in this regard.

However, although the purpose of the Inter-American institutions is to eradicate criminalization of freedom of expression abuses, the case law itself is more nuanced. In fact, in the Case Kimel and other v. Argentina, of 2008, the Inter-American Court held that criminal proceedings do not restrict in and of themselves freedom of thought and expression. ${ }^{54}$ So, in this case, the criminal prosecution legitimation is a priori recognized, but according to the parameters defined by the Court itself to regulate the use of criminal sanctions by the Member (the seriousness of the conduct of the individual who expressed the opinion or issue the information, the intention to cause damage or the injurious purpose with which it was expressed, and the significant damage caused).

\section{Conclusive Remarks}

This brief and schematic analysis of the right to freedom of expression has the purpose of illustrate some elements of the Article 13 of the American Convention on $\mathrm{Hu}$ man Rights in the light of regional contentious practice. The matter is, without doubt, par-

\footnotetext{
52 "In the events in which the right of correction or reply is insufficient to re-establish the right to reputation or honor of those who have been affected by a given exercise of freedom of expression, and recourse may therefore be had to other mechanisms of legal liability, such recourse to the imposition of legal liability must strictly comply with certain specific requirements in addition to the ones mentioned above, namely: (a) Application of the standard of actual malice. In resorting to the imposition of liability for alleged abuses of freedom of expression, the standard of assessment of "actual malic" must be applied; that is, it must be demonstrated that the person expressing the opinion did so with the intent to cause harm and the knowledge that she was disseminating false information, or that she did so with a reckless disregard for the truth of the facts. With regard to communications professionals and journalists, Principle 10 of the IACHR Declaration of Principles on Freedom of Expression provides that "in these cases, it must be proven that in disseminating the news, the social communicator had the specific intent to inflict harm, was fully aware that false news was disseminated, or acted with gross negligence in efforts to determine the truth or falsity of such news." (ORGANIZATION OF AMERICAN STATES, 2009, p. 38).

53 "11. Public officials are subject to greater scrutiny by society. Laws that penalize offensive expressions directed at public officials, generally known as "desacato laws," restrict freedom of expression and the right to information." ${ }_{54}$ Case Kimel $v$. Argentina, para. 26. For further information and additional references see Aguiar (2008, p. 21 e ss).
} 
ticularly relevant for effective protection of human rights in the Americas context. Albeit limited to the available space, the study revealed convergences between Inter-American Court of Human Rights and European Court of Human Rights case law on the subject and, at the same time, important peculiarities relating to the regional contexts of reference. Summarizing, due to relevance recognized to collective dimension of the right to freedom of expression, one could say that in the Inter-American context there is a greater verticalization of the protection of right to freedom of expression, which means more attention to the restrictions that come from public bodies and politicians, still present in the continent, compared to a more ostensive activity of balancing between individual and antinomic rights, implemented by the European Court. Certainly this is due to a different legal regulation and also to the policy choices of the involved institutions.

At the same time, there is an important cross-fertilization phenomenon between the activities of the two courts, topic that should deserve an in-depth analysis elsewhere.

\section{References}

AGUIAR, Asdrúbal. A proposito del caso Kimel vs. Argentina. La Libertad de Expresión: ¿Piedra angular de la democracia? Revista de derecho público, v. 114, p. 21 e ss, 2008.

BERTONI, Eduardo. Hate speech under the American Convention on Human Rights. ILSA journal of international \& comparative law, v. 12, p. 573-574, 2006.

BURGORGUE-LARSEN, Laurence; ÚBEDA DE TORRES, Amaya. The InterAmerican Court of Human Rights: case law and commentary. Oxford: Oxford Universty Press, 2011.

GONZÁLES MORALES, Felipe. Censura judicial y libertad de expresión: sistema interamericano y derecho chileno. Revista IIDH, v. 43, p. 239 e ss, 2006.

GROSSMAN, Claudio. La libertad de expresión en el sistema interamericano de protección de los derechos humanos. In: LEÃO, Renato Zerbini Ribeiro (Org.). Os rumos do direito internacional dos direitos humanos. Ensaios em homenagem ao professor Antônio Augusto Cançado Trindade. Porto Alegre: Safe, 2005.

MORALES, Mariela Antoniazzi. La Democracia y su Piedra Angular: la Libertad de Expresión. Estándares de la Corte Interamericana de Derechos Humanos. In: BOGDANDY, Armin Von; PIOVESAN, Flávia; MORALES, Mariela Antoniazzi (Org.). Direitos Humanos, Democracia e Integração Jurídica. Avançando no diálogo constitucional e regional. São Paulo: Lumen Iuris, 2011, p. 314.

ORGANIZATION OF AMERICAN STATES. American Convention on Human Rights, "Pact of San Jose". Costa Rica, 22 Nov. 1969. Available at: < http://www.refworld.org/docid/3ae6b36510.html>. Access in: 16 Feb. 2016. 
ORGANIZATION OF AMERICAN STATES. Background and Interpretation of the Declaration of Principles. Available at: < http://www.oas.org/en/iachr/expression/ showarticle.asp? artID=132\&lID=1>. Access in: 27 Dec. 2015.

ORGANIZATION OF AMERICAN STATES. The inter-American legal framework regarding the right to freedom of expression. Office of the Special Rapporteur for Freedom of Expression Inter American Commission on Human Rights, 2010. Available at: <http://www.oas.org/en/iachr/expression/docs/publications/INTER-AMERICAN\%20LEGAL\%20FRAMEWORK\%20OF\%20THE\%20RIGHT\%20TO\%20 FREEDOM\%20OF\%20EXPRESSION\%20FINAL\%20PORTADA.pdf > . Access in: 01 Dec. 2015.

ORGANIZATION OF AMERICAN STATES. Violence against journalists and media workers: inter-american standards and national practices on prevention, protection and prosecution of perpetrators. Inter-american commission on human rights, 2014. Available at: <http://www.oas.org/en/iachr/expression/docs/reports/2014_04_22_Violence_WEB.pdf>. Access in: 02 Dec. 2015.

ÚBEDA DE TORRES, Amaya. Freedom of expression under the European Convention on Human Rights: a comparison with the Inter-American System of Protection of Human Rights. Human Rights Brief, American University, Washington College of Law, v. 19, p. 6-9, 2003.

Data da submissão: 15 de dezembro de 2015 Avaliado em: 17 de dezembro de 2015 (Avaliador A) Avaliado em : 18 de dezembro de 2015 (Avaliador B) Avaliado em : 19 de dezembro de 2015 (Avaliador C) Aceito em: 27 de janeiro de 2016 